Original Research Paper

\title{
Effect of Endophytic Treatments on Plant Growth Performance and Disease Incidences in Soybean (Glycine max (L.) Merril) Cultivar JS-335 against Challenge Inoculation with $R$. solani
}

\author{
Jitendra Dalal and Nikhilesh Kulkarni \\ Department of Microbiology, Microbiology Research Laboratory, R.A. Arts, \\ Shri M.K. Comm. and Shri S.R. Rathi Sci. Mahavidyalaya, Washim-444 505 (MS), India
}

Article history

Received: 18-09-2014

Revised: 26-05-2015

Accepted: $18-6-2015$

Corresponding Author: Jitendra Dalal

Department of Microbiology, Microbiology Research Laboratory, R.A. Arts, Shri M.K. Comm. and Shri S.R. Rathi Sci. Mahavidyalaya, Washim-444 505 (MS), India Email: winnerdala129@rediffmail.com

\begin{abstract}
Endophytes could be efficient biological control agent in sustainable crop production and offer unique opportunity for crop protection and biological control. Present study was carried out to investigate the effects of indigenous endophytic microorganisms Pseudomonas sp., Bacillus sp., Burkholderia sp. Streptomyces sp., Actinoplanes sp., Alternaria sp. and Fusarium sp. on plant growth and disease control against challenge inoculation with Rhizoctonia solani in soybean (Glycine max (L.) Merril). It was observed that treatment with endophytes significantly $(\mathrm{p}<0.05)$ improved the seed germination, root, shoot length, Seedling Vigour Index (SVI), root nodulation in soybean. The significant increments were recorded fresh and dry weight, nitrogen, phosphorus and potassium (NPK) uptake and seed yield $(p<0.05)$. The disease incidences were reduced significantly over control $(p<0.05)$. Thus, present studies indicate that utilization of indigenous endophytes may exert more favorable effects on plant health, disease control which ultimately will enhance crop productivity.
\end{abstract}

Keywords: Endophytes, PGPRs, Biocontrol, Soybean (Glycine max (L.) Merril)

\section{Introduction}

Plant-associated microorganisms have been extensively examined for their roles in natural and induced suppressiveness of soil-borne diseases. Because, rhizobacteria and endophytes are part of the natural microflora of healthy plants, they may be considered to be important contributors to plant health and general soil suppressiveness. Biological control has been described as a non-hazardous strategy to reduce crop damage caused by plant pathogens when compared to the chemical control of plant diseases (Wang et al., 2010). A major factor influencing plant growth and health is the microbial population living both in the rhizosphere and as endophytes within healthy plant tissue. Plants may be considered complex microecosystems where, different niches are exploited by a wide variety of microbes. Such niches include not only the external surfaces of plants, but also the internal tissues which endophytic microbe inhabit without apparent harm to the host or external structures (Azevedo et al., 2000).

Even though some success has been achieved in controlling crop pathogens and plant growth promotion by supplementing the crop soil with Plant GrowthPromoting Rhizobacteria (PGPR) and other biocontrol microbial inoculants. However, large number of biocontrol agents fails to be effective due to the difficulty of manipulating the highly complex rhizosphere environment (Conn and Franco, 2004). Exotic strains from commercial inoculants may not survive in local soils due to different edaphic or climatic conditions or may be outcompeted by better adapted native strains during plant colonization resulting in poor performance of PGPR (Calvo et al., 2010). The efficacy of conventional control measures, however, is limited. Hence, there is an increasing need for novel and environmentally sound strategies to control the plant diseases. 
Microbial endophytes are typically defined as plant associated microbes that colonize living internal tissues of plants without causing any visible symptoms or immediate over-negative effects and can be isolated from surface disinfected plant tissue (Wilson, 1995; Zinniel et al., 2002; Hung and Annapurna, 2004). Endophytic microbes include bacteria, actinomycetes and fungi are ubiquitous in most plant species. Endophytes exist in a range of tissue types within a broad range of plants, colonizing the plant systemically, residing latently in intercellular spaces, inside the vascular tissue or within cells (Khan and Doty, 2009). Relatively steady internal environment inside the plant tissues makes endophytes more bioactive than the rhizospheric or others plant associated microorganisms (He et al., 2009).

Endophytes might interact more closely with the host plant and therefore, could be efficient biological control agent in sustainable crop production and offer unique opportunity for crop protection and biological control (Melnick et al., 2008). The use of endophytes can be divided into two categories based on types of activity viz., growth promotion and disease control (Bacon and White, 2000).

Among the plant associated microorganisms, endophytes are regarded as a largely untapped resource for the discovery of isolates with novel antifungal and plant growth promoting traits (Mendes et al., 2007). Endophytic microorganisms have attracted the attention of researchers because of their potential to serve as biocontrol agents (Strobel and Daisy, 2003; Stein, 2005; Ryan et al., 2008). Endophytes living in the healthy tissues of plants are relatively unstudied and may be the potential source of novel natural products for exploitation in agriculture, medicine and other industries (Strobel and Daisy, 2003).

Although, the plant-endophyte interaction has not been fully understood, it has been reported that many isolates provide beneficial effects to their hosts like preventing disease development by synthesizing novel compounds and antifungal metabolites. Several endophytes have been shown to support plant growth and increase nutrient uptake by providing phytohormones, low molecular weight compounds, enzymes, antimicrobial substances like antibiotics and siderophores. Other beneficial effects of endophytes to plants include nitrogen fixation, increased drought resistance, thermal protection, survival under osmotic stress etc. (Khan and Doty, 2009).

Within the framework of integrated plant disease management (IDM) the use of indigenous bacterial endophytes with biocontrol activity is environment friendly and ecologically efficient approach (Prieto et al., 2011). In spite of the great importance of endophytic microorganisms in agricultural ecosystems, only a very small part of the microbial diversity relevant to agriculture was carefully described. The great amount of information regarding the key role of endophytic microbes in agriculture is yet to be explored.

Soybean (Glycine max (L.) Merril) is an Asiatic leguminous plant, occupying large acres of land worldwide for its oil and protein. In recent years, soybean has assumed important position in India. It has well adapted to black soils of central and peninsular India. Major soybean producing states in India including, Madhya Pradesh, Maharashtra and Rajasthan contribute about $97 \%$ to total area and $96 \%$ production of soybean in the country (Namrata et al., 2012). Maharashtra is the second largest soybean producing state in India. It accounts for 34\% of the India's bean production. Soybean is gaining popularity on account of its unique characteristics and adaptability to varied agro-climatic conditions (Pawar et al., 2011).

Washim is an important soybean producing area of Vidarbha region of Maharashtra, occupying 2095 ha of area with production of 2987 tons during 2010-2011 (Crop Production Statistics, Department of Agriculture, Government of Maharashtra). However, due to extreme diversity of pathogens and serious diseases severe plant losses and yield reductions are common in susceptible cultivars of soybean (Zivkovic et al., 2010). The soybean fungal pathogens are prevailing and chiefly intricate to control.

Inspite of increased numbers of reports about beneficial traits of endophytic microbes to crop plants protecting their host against predators and pathogens and promotion of plant growth, there is dearth of information regarding use of different endophytic microorganisms for the management of soil-borne fungal pathogens and growth promotion in soybean. Hence, with the view of plant health and productivity the proposed studies with special reference to indigenous endophytic microbes for soybeans crop cultivar JS-335, as model phytosystem, have been carried out.

\section{Materials and Methods}

\section{Endophytic Microorganisms and R. solani}

In present investigation indigenous endophytic bacteria, actinomycetes and fungi isolated from soybean were utilized to study their effects on plant growth performance and disease control against $R$. solani isolated from diseased Soybean plant. The isolated endophytes were initially screened for in vitro antagonistic activity against R. solani (Zivkovic et al., 2010; Yuan and Crawford, 1995). The antagonist thus obtained were further screened for the ability to exhibit plant growth promoting ability viz., secretion of plant growth regulators (auxins (indole-3-acetic acid (IAA) and indole-3-pyruvic acid (IPyA), gibberellins (GA3) and cytokinins [isopentenyl adenine (iPa), isopentenyl adenosine (iPA) and Zeatin (Z)), $\mathrm{HCN}$ and siderophore conditions adopting standard biochemical methodology (Strzelczyk and Pokojska, 1984; Shirling and 
Gottlieb,1966; El-Tarabily et al., 2009 Tien et al., 1979; Thimmaiah, 2004; Lorck, 2006; Castric and Castric, 1983; Samuel and Muthukkaruppan, 2011; Neilands, 1981; Coleman, 1995; Wijesundera et al., 1995; Logeshwaran et al., 2009).

Studies on Interaction between the Isolated, Pathogens and Endophytes having Dual Attributes on the Growth Performance and Disease Incidences of Soybean

Field experiments were conducted to study the effect of interaction between the isolated pathogens and endophytes with dual attributes (Table 1) on growth performance and disease incidences in soybean cultivar JS-335.

\section{Experimental Site and Soil}

The experiment was conducted at Agriculture Research Farm, Microbiology Research Laboratory, Tondgaon Dist. Washim (MS) India. It is approximately $22 \mathrm{Km}$ away from
Washim city. The soil resembled to be the vertisol type (Fig. 1). Vertsol soil in which there is high content of expansive clay and is usually very dark in color.

\section{Climatic Conditions}

The climate of the district is characterized by hot summer and general dryness throughout the year except during the south-west monsoon season, i.e., June to September. The mean minimum temperature is $12^{\circ} \mathrm{C}$ and mean maximum temperature is $42^{\circ} \mathrm{C}$.

\section{Experimental Details}

The experimentation was carried out during Kharif season of 2012. Micro plots of size $1 \mathrm{~m}^{2}$ were prepared and used further for experimentation adopting randomized block design with three replications the layout of the plan is presented in Fig. 2A, B and C and details of the experiments are presented in Table $2 \mathrm{~A}$ and B. All the experimentation was carried out in plots amended with fungal pathogen $R$. solani sick soil with soybean cultivar JS-335 as the test crop.

Table 1. Screened endophytic isolates with dual ability of antagonism against $R$. solani and plant growth promotion

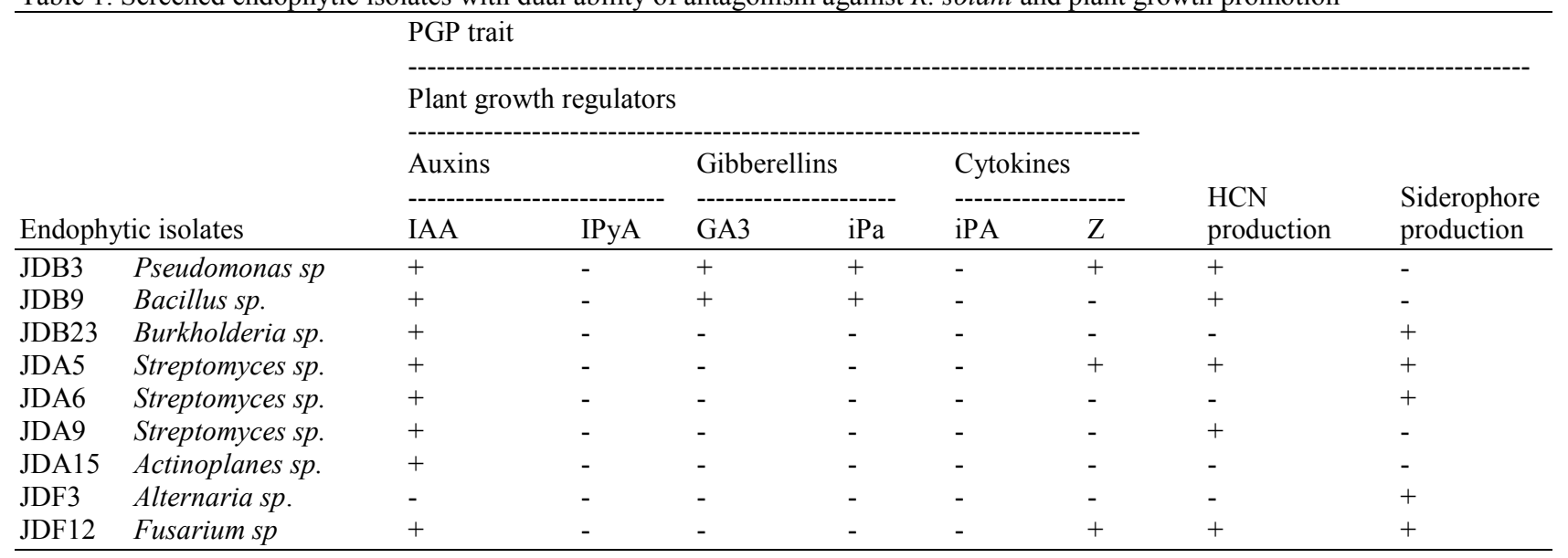

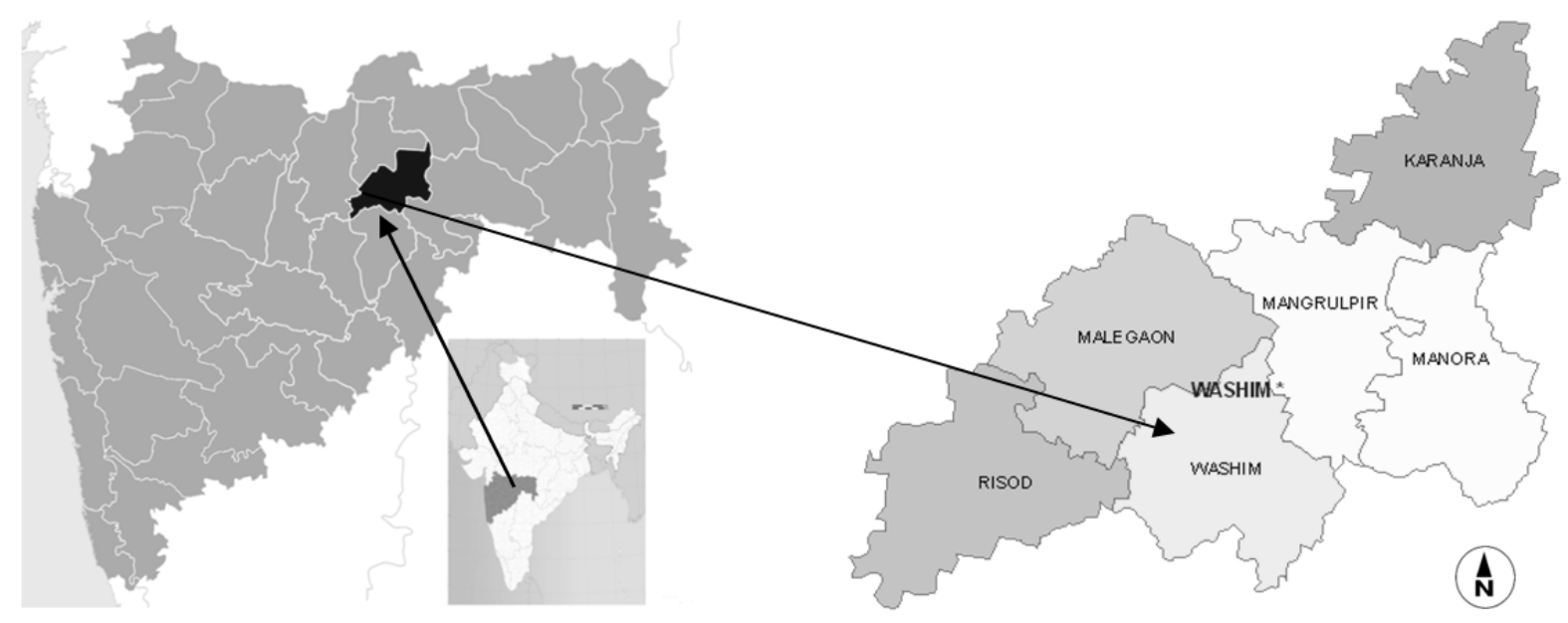

Fig. 1. Location of study area 


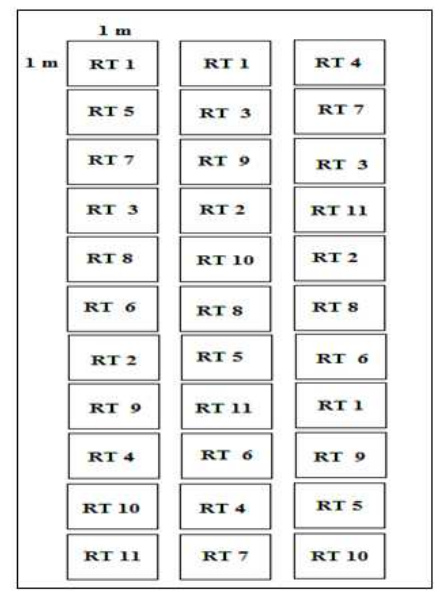

(A)

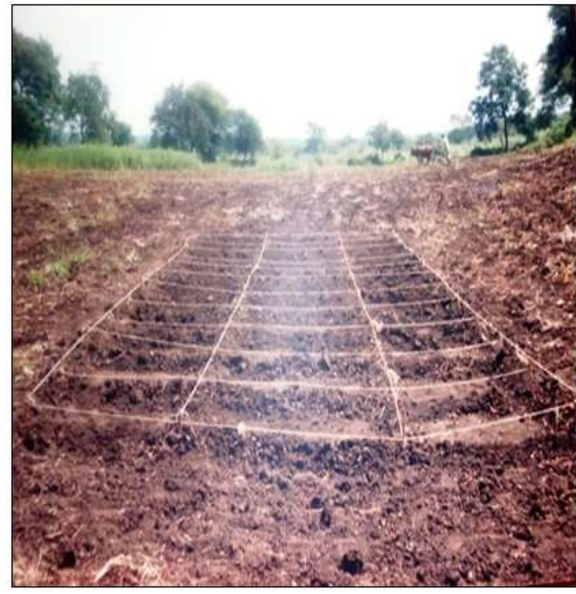

(B)

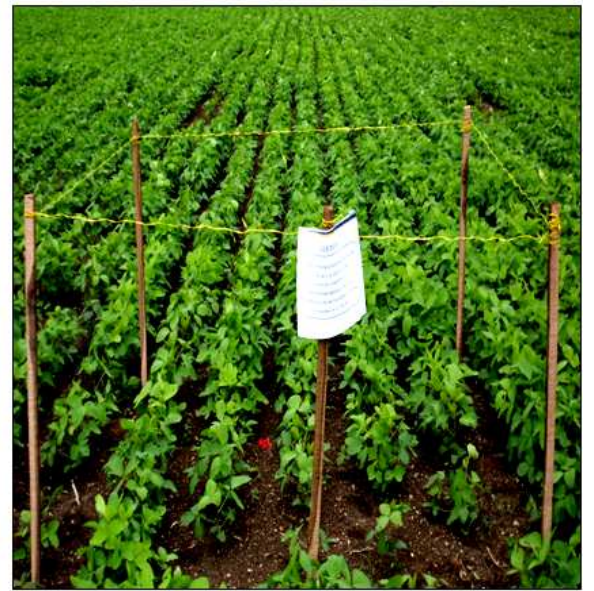

(C)

Fig. 2. Plan of layout of the experimental sites

Table 2A. Details of experiments

\begin{tabular}{ll}
\hline Particulars & \\
\hline Ploughing & 03.06 .2012 \\
Harrowing & 05.07 .2012 \\
Layout of the field & 05.07 .2012 \\
Treatments & 11 \\
Replications & 3 \\
Design of experiment & Randomized block design \\
Microplot size $\left(\mathrm{m}^{2}\right)$ & 1 \\
Spacing $(\mathrm{cm})$ & 30 \\
Crop variety & JS-335 \\
Date of sowing & 06.07 .2012 \\
Method of sowing & Drilling \\
Seed rate $(\mathrm{kg} / \mathrm{ha})$ & 75 \\
Recommended NPK & $30: 75: 30$ \\
dose and date of application & \\
Harvesting of crop & 15.10 .2012 \\
\hline
\end{tabular}

Table 2B. Treatment details R. solani sick soil

\begin{tabular}{ll}
\hline Treatment & Details \\
\hline RT1 & Seed treatment with bacterial isolateJDB3 \\
RT2 & Seed treatment with bacterial isolateJDB9 \\
RT3 & Seed treatment with bacterial isolate JDB23 \\
RT4 & Seed treatment with actinomycete isolate JDA5 \\
RT5 & Seed treatment with actinomycete isolate JDA6 \\
RT6 & Seed treatment with actinomycete isolate JDA9 \\
RT7 & Seed treatment with actinomycete isolate JDA15 \\
RT8 & Seed treatment with fungal isolate JDF3 \\
RT9 & Seed treatment with fungal isolate JDF12 \\
RT10 & RT1+RT2+RT3+RT4+RT5+RT6+RT7+RT8+RT9 \\
RT11 & Seed treatment with sterile dist. water (Control) \\
\hline
\end{tabular}

\section{Preparation of R. solani Sick Soil}

The fungal pathogen sick soil was prepared as described by Totawar (2001) with slight modifications. $R$. solani was enriched separately in $250 \mathrm{~mL}$ of potato dextrose broth and the inoculum was build upto $500 \mathrm{~mL}$ each. The inoculum treatment was separately given to cultivated seedlings at 15 DAS. Further the seedlings were examined for disease development at 30 DAS. The screened diseased plants were again processed for isolation of fungal pathogen. Thereafter, the process from the inoculum build up was repeated for six months so as to get the virulent soil. The virulent soil was further fortified manually $(10 \%$ per $\mathrm{kg})$ on the surface of experimental plots. The virulent soil fortified experimental plots were further considered as sick soil microplots. Whereas, microplots without fortification of fungal pathogens were maintained as control.

\section{Treatment Details}

Soybean seeds were treated with endophytes alone and in combination. Test crops without endophyte treatment were maintained as control. The charcoal based endophytic bio-inoculants were produced (Chandrashekhara et al., 2007; Gopalakrishnan et al., 2012; Sudisha et al., 2006) and used for seed treatments.

\section{Seed Treatment with Endophytic Bio-Inoculants}

The seeds were surface sterilized with $2 \%$ sodium hypochlorite for $2 \mathrm{~min}$ and washed with sterile distilled water and further blotted dry with sterile blotting paper. Seeds were treated with $10 \%(\mathrm{w} / \mathrm{v})$ jiggery solution and allowed to dry for $5 \mathrm{~min}$. Seed treatment was done using charcoal based inoculants (25 gm/ $/ \mathrm{gg}$ of seeds). The charcoal based inoculants were then added to seeds and mixed uniformly so as to achieve a homogenous coat over seed. Treated seeds were stored in cool and dry place at room temperature away from sunlight. The treated seeds were sown in respective microplots. Seeds without endophytic treatments were maintained as control. The treatments were designated as $\mathrm{RT}_{1-11}$, representing treatments in the $R$. solani sick soil. Necessary agricultural operations viz., thinning, hoeing and weeding were carried out as and when required with the help of local labors. 
Studies on Effect of Endophytic Treatments on Growth Performance and Disease Incidences

Three plants from each plot in the net plot area were selected randomly and tagged for recording different biometric observations. Mean of three plants was considered for analysis. Germination count of each plot was taken and per cent germination was calculated on 15th Days After Sowing (DAS). Vegetative growth parameters viz., per cent germination, root-shoot length, Seedling Vigor Index (SVI), fresh and dry weight and NPK uptake was recorded at 30th DAS for both treated and untreated control plant. Seedlings were uprooted from each treatment plot on 30th DAS without disturbing the root system and root-shoot length $(\mathrm{cm})$ were measured. Seedling Vigor Index (SVI) was calculated by the formula (Hatwalene, 1993):

\section{S. V. I $=\{($ Root length $)+($ Shoot length $)\} X$ Germination \%}

\section{Root Nodulation Count}

Randomly selected plants were uprooted at 45 th DAS along with soil mass. The root system was dipped in water to remove adhering soil and enough care was taken to keep the root system and nodules intact so that none of the nodules were lost. The nodules were separated from roots, washed, counted and further recorded as number of nodules per plant (Meenakshi, 2008).

\section{Estimation of Fresh and Dry Weight}

The fresh and dry weight were recorded on 30th DAS and expressed in gram per plant (g/plant).The fresh weight of the plants was determined by weighing the individual plants immediately after harvesting. The dry weight was estimated after drying the plants at $65^{\circ} \mathrm{C}$ in an oven for $12 \mathrm{hr}$.

\section{Estimation of NPK Uptake}

The collected plant samples were processed for the estimation NPK uptake adopting standard methods. Estimation of Nitrogen $(\mathrm{N})$ by following the Microkjeldhal method (Jackson, 1973), Phosphorus (P) uptake by Vanadomolybdate reagent and potassium (K) was estimated by atomizing the diluted plant extract in the flame photometer as described by Jackson (1973).

\section{Yield}

At harvest, yield of soybean seeds per net plot was recorded $(\mathrm{kg} / \mathrm{plot})$ and expressed in $\mathrm{kg} / \mathrm{ha}$ (Meenakshi, 2008).

\section{Disease Incidences}

Observations were also made for the existence of number of healthy plant units; number of infected plant units from each plot was recorded at 30th DAS and per cent disease incidence was calculated using formula (Gilligan, 1983):

$$
\text { Disease incidence }(\%)=\frac{\text { No. of infected plantsunits }}{\text { Total No. of }(\text { healthy }+ \text { infected })} \times
$$

\section{Results}

Effect of Endophytic Treatments on Plant Growth Performance of Soybean Cultivar JS-335 against Challenge Inoculation with R. solani

Data on effect of endophytic treatments on plant growth parameters viz., germination, root and shoot length, Seedling Vigor Index (SVI), root nodulation fresh and dry weight, NPK uptake and seed yield was recorded against challenge inoculation with $R$. solani.

\section{Germination}

Results on the influence of endophytic treatments on germination of soybean in $R$. solani sick soil are presented in Table 3. The endophytic treatments significantly improved the germination of soybean over uninoculated control. Maximum germination was recorded at consortial treatment RT10 (79.25\%) over uninoculated control RT11 (57.03\%). Among the individual treatments the maximum germination was recorded in bacterial treatment RT1 $(73.33 \%)$ followed by treatment RT2 $(71.85 \%)$. However, germination was observed to be minimum in case of actinomycete treatment RT5 (50.37\%) and fungal RT8 (54.07\%) lower germination was recorded as compared to uninoculated control. Endophytic treatment RT10 was found to be significantly higher and was at par with treatment RT1 and RT2. Whereas, other treatments viz., RT3, RT5, RT6, RT7 and RT9 were found to be insignificant in improving germination as compared to control RT11.

\section{Root Length}

Results on the influence of endophytic treatments on root length of soybean at 30th DAS in $R$. solani sick soil are presented in Table 3.

Significant increase in root length was recorded in endophytic treatments over uninoculated control. Maximum root length was recorded at individual bacterial treatment RT2 $(7.73 \mathrm{~cm})$ over uninoculated control RT11 $(4.30 \mathrm{~cm})$. Root length values were on par at individual bacterial RT1 $(7.50 \mathrm{~cm})$, RT3 $(7.43 \mathrm{~cm})$ and consortial treatment RT10 $(7.50 \mathrm{~cm})$. However, root length in actinomycete treatment RT4 $(4.06 \mathrm{~cm})$ was observed to be lower as compared to control RT11. 
Jitendra Dalal and Nikhilesh Kulkarni / American Journal of Agricultural and Biological Sciences 2015, 10 (2): 99.110 DOI: 10.3844/ajabssp.2015.99.110

Table 3. Effect of endophytic treatments on growth parameters of soybean in $R$. solani sick soil

\begin{tabular}{|c|c|c|c|c|c|}
\hline \multirow[b]{2}{*}{$\begin{array}{l}\text { Treatment } \\
\text { details }\end{array}$} & \multicolumn{5}{|c|}{ Germination } \\
\hline & Mean & $\%$ & $\begin{array}{l}\text { Mean root } \\
\text { length }(\mathrm{cm})\end{array}$ & $\begin{array}{l}\text { Mean shoot } \\
\text { length }(\mathrm{cm})\end{array}$ & $\begin{array}{r}\text { Mean seedling vigor } \\
\text { index (SVI) }\end{array}$ \\
\hline RT1 & 33.00 & 73.33 & 7.50 & 12.60 & 1474.00 \\
\hline RT2 & 32.33 & 71.85 & 7.73 & 14.53 & 1599.90 \\
\hline RT3 & 27.33 & 60.74 & 7.43 & 13.96 & 1299.85 \\
\hline RT4 & 22.66 & 50.37 & 4.06 & 9.40 & 678.32 \\
\hline RT5 & 26.33 & 58.51 & 4.63 & 10.60 & 891.432 \\
\hline RT6 & 28.00 & 62.22 & 4.30 & 9.56 & 862.81 \\
\hline RT7 & 29.00 & 64.44 & 5.10 & 8.23 & 859.25 \\
\hline RT8 & 24.33 & 54.07 & 5.73 & 10.63 & 885.01 \\
\hline RT9 & 26.33 & 58.51 & 4.30 & 6.70 & 643.70 \\
\hline RT10 & 35.66 & 79.25 & 7.50 & 13.20 & 1640.67 \\
\hline RT11 & 25.66 & 57.03 & 4.30 & 7.56 & 676.83 \\
\hline F-Test & Sig & & Sig & Sig & Sig \\
\hline $\mathrm{SE}(\mathrm{m})$ & 1.55 & & 0.21 & 0.20 & 21.48 \\
\hline $\mathrm{CD}(5 \%)$ & 4.57 & & 0.61 & 0.60 & 63.19 \\
\hline
\end{tabular}

Whereas, root length in actinomycete treatment RT6 $(4.30 \mathrm{~cm})$ and fungal treatment RT9 $(4.30 \mathrm{~cm})$ was observed to be at par with control treatment RT11. Endophytic treatments RT1, RT2, RT3, RT7, RT8 and RT9 significantly increased root length as compared to uninoculated control RT11 whereas RT5 was found to be statistically insignificant in improving root length.

\section{Shoot Length}

Data on the influence of endophytic treatments on shoot length of soybean at 30th DAS in $R$. solani sick soil are presented in Table 3. Endophytic treatments significantly increased shoot length over control. Maximum shoot length was recorded in individual bacterial treatments RT2 $(14.53 \mathrm{~cm})$ followed by treatment RT3 $(13.96 \mathrm{~cm})$, RT1 $(12.60 \mathrm{~cm})$ and consortial treatment RT10 $(13.20 \mathrm{~cm})$ over uninoculated control RT11 $(7.56 \mathrm{~cm})$. However, shoot length in individual fungal treatment RT9 $(6.70 \mathrm{~cm})$ was found to be lower as compared to control RT11. Endophytic treatments RT1, RT2, RT3, RT10 were significantly high in improving shoot length whereas treatment RT5 was insignificant as compared to control.

\section{Seedling Vigor Index (SVI)}

Data on the influence of endophytic treatments on SVI of soybean at 30th DAS in $R$. solani sick soil is presented in Table 3. Endophytic treatments significantly enhanced SVI of soybean. However, the degree of enhancement varied treatments. Maximum SVI was recorded in bacterial treatment RT2 (1599.90) followed by consortial treatment RT10 (1640.67), bacterial treatment RT1 (1474.00) over uninoculated control RT11 (676.83). However, SVI in actinomycete treatment RT4 (678.32) and in fungal treatment RT9 (643.70) was found to be lower as compared control RT11.
Endophytic treatments RT1, RT2, RT3 and RT10 were significantly higher in improving SVI of soybean whereas treatments RT4 and RT9 were insignificant as compared to control.

\section{Root Nodulation}

The data on nodulation as influenced by endophytic treatments at 45th DAS in $R$. solani is presented in Table 4. The nodulation was significantly increased in all endophytic treatments. However, nodulation was varied between individual and consortial treatments. Maximum no. of nodules were recorded in consortial treatment RT10 (59) followed by bacterial RT1 (46), RT4 (43) and RT2 (42) as compared to uninoculated control RT11 (18). All the endophytic treatments significantly improved root nodulation. Endophytic treatments RT1, RT2, RT4 and RT10 were significantly higher in improving nodulation as compared to control RT11.

\section{Fresh Weight and Dry Weight}

Results on the influence of endophytic treatments on fresh and dry weight ( $\mathrm{g}$ ) of soybean in $R$. solani sick soil are presented in Table 5. Significant improvement was observed in fresh and dry weight in endophytic treatments over uninoculated control. However, the degree of improvement varied between treatments. Maximum fresh weight was recorded in consortial treatment RT10 (18.40 g) and minimum fresh weight was recorded in individual actinomycete treatment RT6 $(11.50 \mathrm{~g})$ as compared to control RT11 (8.40 g). Fresh weight values recorded were on par at bacterial treatments RT1 (16.93 g), RT2 (17.86 g) and RT3 $(17.73 \mathrm{~g})$. All the endophytic treatments significantly improved fresh weight of soybean however treatments RT1, RT2, RT3 and RT10 were highly significant as compared to other treatments. 
Table 4. Effects of endophytic treatments on root nodulation in soybean in R. solani sick soil

\begin{tabular}{ll}
\hline $\begin{array}{l}\text { Treatment } \\
\text { details }\end{array}$ & $\begin{array}{l}\text { Average no. } \\
\text { of nodules/plant }\end{array}$ \\
\hline RT1 & 46 \\
RT2 & 42 \\
RT3 & 36 \\
RT4 & 43 \\
RT5 & 33 \\
RT6 & 32 \\
RT7 & 35 \\
RT8 & 36 \\
RT9 & 36 \\
RT10 & 59 \\
RT11 & 18 \\
F-Test & Sig \\
SE(m) & 1.60 \\
CD $(5 \%)$ & 4.70 \\
\hline
\end{tabular}

Table 5. Effects of endophytic treatments on fresh and dry weight of soybean DAS in $R$. solani sick soil

\begin{tabular}{lll}
\hline $\begin{array}{l}\text { Treatment } \\
\text { details }\end{array}$ & $\begin{array}{l}\text { Mean fresh } \\
\text { weight }(\mathrm{g})\end{array}$ & $\begin{array}{l}\text { Mean dry } \\
\text { weight }(\mathrm{g})\end{array}$ \\
\hline RT1 & 16.93 & 7.20 \\
RT2 & 17.86 & 7.86 \\
RT3 & 17.73 & 7.60 \\
RT4 & 12.83 & 6.36 \\
RT5 & 13.43 & 6.20 \\
RT6 & 11.50 & 5.30 \\
RT7 & 14.26 & 6.26 \\
RT8 & 13.46 & 5.53 \\
RT9 & 12.26 & 4.66 \\
RT10 & 18.40 & 8.80 \\
RT11 & 8.40 & 4.56 \\
F-Test & Sig & Sig \\
SE(m) & 0.64 & 0.26 \\
CD $(5 \%)$ & 1.87 & 0.76 \\
\hline
\end{tabular}

Table 6. Effects of endophytic treatments on NPK uptake in soybean in $R$. solani sick soil

\begin{tabular}{llll}
\hline $\begin{array}{l}\text { Treatment } \\
\text { details }\end{array}$ & $\begin{array}{l}\text { Average N } \\
\text { uptake }(\mathrm{kg} / \mathrm{ha})\end{array}$ & $\begin{array}{l}\text { Average P } \\
\text { uptake }(\mathrm{kg} / \mathrm{ha})\end{array}$ & $\begin{array}{l}\text { Average K } \\
\text { uptake }(\mathrm{kg} / \mathrm{ha})\end{array}$ \\
\hline RT1 & 31.50 & 5.86 & 30.66 \\
RT2 & 30.33 & 5.26 & 30.20 \\
RT3 & 29.00 & 4.93 & 29.33 \\
RT4 & 28.16 & 6.00 & 28.23 \\
RT5 & 26.73 & 6.20 & 29.80 \\
RT6 & 27.00 & 5.13 & 27.56 \\
RT7 & 26.10 & 6.16 & 27.00 \\
RT8 & 27.80 & 6.66 & 27.36 \\
RT9 & 26.16 & 5.43 & 28.26 \\
RT10 & 32.63 & 6.73 & 30.63 \\
RT11 & 23.50 & 3.56 & 21.03 \\
F-Test & Sig & Sig & Sig \\
SE(m) & 2.89 & 2.46 & 2.52 \\
CD $(5 \%)$ & 8.51 & 7.23 & 7.40 \\
\hline
\end{tabular}

Maximum dry weight $(8.80 \mathrm{~g})$ was recorded in consortial treatment RT10 whereas it was minimum at actinomycete treatment RT6 (5.30 g) over uninoculated control (4.56 g). Whereas, dry weight values were on par at bacterial treatments RT2 (7.86 g) and RT3 (7.60 g). Significant improvement was recorded at all endophytic treatment except treatment RT9. Treatments RT1, RT2, RT3 and RT10 were highly significant in improving dry weight over other treatments.

\section{NPK Uptake}

The data on NPK uptake at 30th DAS as influenced by endophytic treatments is presented in Table 6 . NPK uptake was significantly increased in all endophytic treatments. Maximum $\mathrm{N}$ uptake was recorded in consortial treatment RT10 (32.63 kg/ha) followed by bacterial RT1 (31.50 kg/ha) and RT2 (30.33 kg/ha) whereas minimum $\mathrm{N}$ uptake was recorded at actinomycete RT7 (26.10 kg/ha) followed by fungal RT9 (26.16 kg/ha) as compared to uninoculated control RT11 $(23.50 \mathrm{~kg} / \mathrm{ha})$. Endophytic treatments RT1, RT2 and RT10 were highly significant in improving $\mathrm{N}$ uptake as compared to other treatments.

Maximum $\mathrm{P}$ uptake was recorded in consortial treatment RT10 $(6.73 \mathrm{~kg} / \mathrm{ha})$ followed by fungal RT8 $(6.66 \mathrm{~kg} / \mathrm{ha})$ whereas it was minimum at bacterial treatment RT3 (4.93 kg/ha) and actinomycete RT6 (5.13 $\mathrm{kg} / \mathrm{ha}$ ) as compared to control RT11 (3.56 kg/ha). P uptake was significantly higher at treatments RT8 and RT10 as compared to other treatments.

Maximum $\mathrm{K}$ uptake was recorded at bacterial treatment RT1 (30.66 kg/ha) followed by consortial RT10 (30.63 kg/ha) and bacterial RT2 (30.20 kg/ha) whereas, it was minimum at actinomycete treatment RT7 $(27.0 \mathrm{~kg} / \mathrm{ha})$ as compared to control RT11 (21.03 kg/ha). All endophytic treatments significantly improved $\mathrm{K}$ uptake. Treatments RT1, RT2 and RT10 were significantly higher as compared to other treatments.

\section{Seed Yield}

The data on seed yield ( $\mathrm{kg} / \mathrm{ha})$ as influenced by endophytic treatments is presented in Table 7 . The seed yield was significantly increased in endophytic treatments. However, seed yield was varied among the treatments. Maximum seed yield was recorded in consortial treatment RT10 (1380.33 kg/ha) followed by bacterial RT2 (1221.00 kg/ha), RT3 (1180 kg/ha) and RT1 $(1129.33 \mathrm{~kg} / \mathrm{ha})$ as compared to uninoculated control RT11 (809.67 kg/ha).

Endophytic treatments RT1, RT2, RT3, RT4 and RT10 were significantly higher in improving seed as compared to other treatments and uninoculated control RT11. However, actinomycete treatments RT6 and fungal RT9 were found to be statistically insignificant as compared to control. 
Table 7. Effects of endophytic treatments on seed yield of soybean in $R$. solani sick soil

\begin{tabular}{ll}
\hline Treatment details & Seed yield $(\mathrm{kg} / \mathrm{ha})$ \\
\hline RT1 & 1129.33 \\
RT2 & 1221.00 \\
RT3 & 1180.30 \\
RT4 & 1016.00 \\
RT5 & 954.33 \\
RT6 & 825.00 \\
RT7 & 884.33 \\
RT8 & 979.66 \\
RT9 & 887.00 \\
RT10 & 1380.33 \\
RT11 & 809.66 \\
F-Test & Sig \\
SE $(m)$ & 27.99 \\
CD $(5 \%)$ & 82.35 \\
\hline
\end{tabular}

Table 8. Effects of endophytic treatments on disease incidences in soybean in R. solani sick soil

\begin{tabular}{lll}
\hline $\begin{array}{l}\text { Treatment } \\
\text { details }\end{array}$ & $\begin{array}{l}\text { No. of } \\
\text { infected plants }\end{array}$ & $\begin{array}{l}\text { Disease } \\
\text { incidence (\%) }\end{array}$ \\
\hline RT1 & 5.33 & 16.16 \\
RT2 & 6.66 & 20.62 \\
RT3 & 5.66 & 20.73 \\
RT4 & 5.333 & 23.53 \\
RT5 & 8.00 & 30.38 \\
RT6 & 6.00 & 21.42 \\
RT7 & 7.33 & 25.28 \\
RT8 & 7.00 & 28.77 \\
RT9 & 5.667 & 21.52 \\
RT10 & 4.667 & 13.08 \\
RT11 & 13.00 & 50.66 \\
F-Test & Sig & \\
SE(m) & 0.51 & \\
CD $(5 \%)$ & 1.5 & \\
\hline
\end{tabular}

Studies on Interaction between the Isolated Pathogens and Endophytes with Dual Attributes on Disease Incidences in Soybean

Endophytic microbes with antagonistic and plant growth promoting activity were utilized for interaction studies between the isolated fungal pathogens of soybean. The effect of endophytic microbes on disease incidences was evaluated in soybean cultivar JS-335 against challenge inoculation with $R$. solani.

Disease incidences on soybean against challenge inoculation with $R$. solani were recorded from endophytic treatment at 30th DAS and the results are presented in Table 8. All the endophytic treatments were found effective in reducing the disease incidences as compared to uninoculated control $(50.66 \%)$. However, the degree of disease incidences varied between the treatments and ranged between 13.08-30.38\%. Maximum protection was offered by the consortial treatment RT10 $(13.08 \%)$ followed by bacterial RT1 $(16.16 \%)$ as compared control RT11. All endophytic treatments significantly reduced disease incidences however; treatment RT10 was highly significant in reducing the disease incidences.

\section{Discussion}

Endophytic microorganisms promote the growth of host plant in various ways and they protect the host plant from pathogens. Our findings are in support with various reports. Endophytic bacteria enhance plant growth by producing plant growth regulators such as gibberellins, cytokinins and indole acetic acid, which directly or indirectly promote plant growth and development (Holland, 1997; Barka et al., 2002). Bhowmik et al. (2002) reported that cotton seed bacterization with the endophyte Endo PR8 was highly effective in reducing cotyledonary infection with Xam. Bacterized grapevines had a greater fresh weight of the shoots and roots and faster growth with more lignin deposits (Barka et al., 2002).

Endophytic bacteria from cotton tissues led to better seed germination and better control of cotton wilt caused by $V$. dahliae (Fu et al., 1999). Mondal et al. (1999) found that five strains of Pseudomonas inhibited Xam, increased cotton seed germination by $12.8 \%$ and improved normal seedling growth by $22.4 \%$. In two field trials, treatment with Bacillus pumilus strain INR7, isolated from a surface-sterilized stem of a surviving cucumber plant in a field heavily infested with cucurbit wilt disease, caused by Erwinia tracheiphila, resulted in significant growth promotion relative to the nontreated control in cucumber (Wei et al., 1996).

Endophytic fungi, residing in the root tissues can play pivotal role in host-plant growth by influencing mineral composition, plant hormonal balance, chemical composition of root exudates, soil structure and plant protection against biotic and abiotic stresses (Waller et al., 2005; Rodriguez et al., 2008; Redman et al., 2011). Previous studies have shown that endophytic fungal association can significantly increase plant biomass and growth and also elaborated the beneficial effects of endophytic fungi on the growth responses of hostplants under various stress conditions (Waller et al., 2005; Hamilton et al., 2010; Redman et al., 2011; Khan et al., 2012).

Plant-fungus relationship has been proclaimed a pivotal source for plant growth and development (Rodriguez and Redman, 2008). Endophytic fungi have been regarded as plant protectant and growth regulator during normal and extreme environmental conditions. Various novel endophytic fungal species like Piriformospora indica, Neotyphodium sp., Curvularia protuberate and Colletotrichum sp. etc have been known to improve plant growth during abiotic stress conditions. Penicillium species have been known as a vital source for bioactive secondary metabolites. Some strains of this genus also produce plant growth regulators like gibberellins, auxin, etc. (Khan et al., 2013). 
Rajendran et al. (2006) studied the effect of indigenous bacterial endophytic strains on plant growth promotion of cotton. 133 endophytic bacteria were isolated from the healthy roots, stems, leaves and seeds of cotton plants. Endophytic Bacillus isolates EPCO 102 (leaf isolate) and EPCO 16 (root isolate) were found to increase the vigour index of cotton seedlings significantly, with a maximum vigour index of 1404.55 for cotton seedlings treated with EPCO 102 suspension, compared with a vigour index of 226.4 with the untreated controls.

Growth-promoting activity of the endophytic fungus Piriformospora indica, resulted in enhanced barley grain yield (Waller et al., 2005). During the first 4 weeks of barley development, shoot fresh weight of infested plants was up to 1.65 times higher compared with control plants. $P$. indica-infested Annabell showed an increase in grain yield of 11per cent, mainly because of a higher number of ears per plant. In cultivar Ingrid, the grain yield increase was $5.5 \%$.

A hyaline sterile fungus forming epiphyllous mycelial nets was isolated from meristem cultures of Mentha piperita (Mucciarelli et al., 2002). Histological studies indicated that the culture isolate is able to colonize stems and leaves with no damage to the host plant. In vitro grown peppermint plants displayed enhanced vegetative growth when infected by the fungus, with mycelium extending from green tissues to growing rootlets.

Hipol (2012) isolated 36 fungal endophytes from apparently healthy sweet potato plants from leaves, stems and roots collected from Baguio City. Among the isolates, only P3AL2c and P3BS1c significantly enhanced growth of paclobutrazol treated rice seedlings. They further demonstrated that the significant increase in plant length for the seedlings treated with the culture filtrates of P3AL2c and P3BS1c were due to the presence of growth promoting metabolites from these fungal endophytes. Treatment of the IR 64 seeds with paclobutrazol, a GA biosynthesis inhibitor, suppresses the endogenous GAs production by blocking its biosynthesis pathway in the plant. Also, the growth media were devoid of nutrients, it being water agar only. As such, growth promotion in the test seedlings can be attributed to the activity of plant growth promoting secondary metabolites from fungal culture filtrates.

Endophytic microbes secreting plant growth regulating compounds are of great agronomic importance to enhance crop yield and quality. These growth regulating compounds can affect plant development as well as support plant growth in instances of biotic and abiotic stress such as tolerance to herbivory, heat, salt, disease and drought and increased below and above ground biomass.

In present investigation the potential of endophytic microbes in reducing the disease incidences has been studied. Significant reductions in the diseases incidences were observed. Our findings correlate with reports of other workers. Application of strains B. pumilus strain SE34 and Pseudomonas fluorescens strain $89 \mathrm{~B}-61$ by incorporation into the potting medium at the time of planting elicited significant reductions in disease severity when $P$. infestans was inoculated onto leaves 5 weeks after planting in tomato (Yan et al., 2002).

Rajendran et al. (2006) tested endophytic bacterial strains for their effectiveness against Xam in potted cotton plants along with plantomycin as a chemical check. They found that with plantomycin at $100 \mathrm{ppm}$ the lowest incidence $(8.38 \%)$ of BBC was recorded 60 DAS, followed by Bacillus isolate EPCO $102+$ chitin (14.853\%). Bacillus isolate EPCO 16 and Pseudomonas fluorescens Pf1 were similar in their effectiveness against Xam. Plants without any endophytic bacteria had the highest $\mathrm{BBC}$ incidence (40.56\%).

Coombs et al. (2004) screened 38 actinobacterial strains isolated from wheat, representing Streptomyces, Microbispora, Micromonospora and Nocardioides, for their antifungal potential against Rhizoctonia solani, Pythium sp. and Gaeumannomyces graminis var tritici (the causal agent of take-all disease in wheat) both in vitro and by bioassays. The analyses revealed that $64 \%$ of the strains had antifungal properties in in vitro assays and 17 strains were efficient in planta (in steamed soil) against take-all disease. The active isolates were also effective under field conditions in the biocontrol against take-all as well as Rhizoctonia (Coombs et al., 2004).

The cumulative yield of marketable cucumber fruit was also significantly enhanced by endophytic Bacillus pumilus strain INR7 in both field trials. In the same study, strain 89B-61 also increased plant growth and yield and reduced the incidence of both angular leaf spot and anthracnose. In a subsequent field trial, INR7 reduced the severity of cucurbit wilt (Zehnder et al., 2001). In addition, the severity of angular leaf spot, following inoculation with Pseudomonas syringae pv. lachrymans and the severity of naturally occurring anthracnose were significantly reduced by INR7.

\section{Conclusion}

It was observed that endophytic treatments improved the growth performance of soybean against the challenge inoculation with $R$. solani. Plant growth parameters viz., per cent germination, root-shoot length, Seedling Vigor Index (SVI), root nodulation, fresh and dry weight and NPK uptake and yield were significantly enhanced over the uninoculated control. Diseases incidences in soybean were significantly reduced due to the endophytic treatments against all the six fungal pathogens of soybean. It was observed that endophytic treatments showed better plant growth and plant protection as compared to uninoculated control. Among the treatments, single treatment performed better than uninoculated control whereas consortial treatments 
performed better over single treatment. Thus, present studies indicate that utilization of indigenous endophytes may exert more favorable effects on plant health, disease control which ultimately will enhance crop productivity.

\section{Funding Information}

Authors are grateful to University Grants Commission, New Delhi, for providing financial assistance under the scheme of major research project as per $\mathrm{XI}^{\text {th }}$ plan.

\section{Author's Contributions}

Jitendra Dalal and Nikhilesh Kulkarni: Designed and planned the current research work and analyzed and interpreted the results.

Jitendra Dalal: Conducted the experiments and collected the data.

\section{Ethics}

Authors declare no competing interest.

\section{References}

Azevedo, J.L., W. Maccheroni, J.O. Pereira and W.L. de Araujo, 2000. Endophytic microorganisms: A review on insect control and recent advances on tropical plants. Electron. J. Biotechnol., 3: 20-00.

Bacon, C.W. and J.F.White, 2000. Microbial Endophytes. 1st Edn., CRC Press, ISBN-10: 0824788311, pp: 500.

Barka, E.A., S. Gognies, J. Nowak, J.C. Audran and A. Belarbi, 2002. Inhibitory effect of endophyte bacteria on Botrytis cinerea and its influence to promote the grapevine growth. Biol. Control, 24: 135-142. DOI: 10.1016/S1049-9644(02)00034-8

Bhowmik, B., R.P. Sing, J. Jayaram and J.P. Verma, 2002. Population dynamics of cotton endophytic Pseudomonas, their antagonism and protective action against the major pathogens of cotton. Indian Phytopath., 55: 124-132.

Calvo, P., E. Ormeno-Orrillo, E. Martínez-Romero and D. Zuniga, 2010. Characterization of Bacillus isolates of potato rhizosphere from andean soils of Peru and their potential PGPR characteristics. Braz. J. Microbiol., 41: 899-906. DOI: $10.1590 / \mathrm{S} 1517-83822010000400008$

Castric, K.F. and P.A. Castric, 1983. Method for rapid detection of cyanogenic bacteria. Appl. Environ. Microbiol., 45: 700-702. PMID: 16346217

Chandrashekhara, S. Niranjanraj, S.A. Deepak, K.N. Amruthesh and N.P. Shetty et al., 2007. Endophytic bacteria from different plant origin enhance growth and induce downy mildew resistance in pearl millet. Asian J. Plant Pathol., 1: 1-11.

DOI: 10.3923/ajppaj.2007.1.11

Coleman, W.H., 1995. Siderophores. Bioscience, 21: 10-14.
Conn, V.M. and C.M.M. Franco, 2004. Analysis of the endophytic actinobacterial population in the roots of wheat (Triticum aestivum L.) by terminal restriction fragment length polymorphism and sequencing of $16 \mathrm{~s}$ rRNA clones. Appl. Environ. Microbiol., 70: 1787-1794.

DOI: 10.1128/AEM.70.3.1787-1794.2004

Coombs, J.T., P.P. Michelsen and C.M.M. Franco, 2004. Evaluation of endophytic actinobacteria as antagonists of Gaeumannomyces graminis var. tritici in wheat. Biol. Control, 29: 359-366. DOI: 10.1016/j.biocontrol.2003.08.001

Crop Production Statistics, Department of Agriculture, Government of Maharashtra.

El-Tarabily, K.A., A.H. Nassar, G.E. Hardy and K. Sivasithamparam 2009. Plant growth promotion ssand biological control of Pythium aphanidermatum, a pathogen of cucumber, by endophytic actinomycetes. J. Appl. Microbiol., 106: 13-26.

Fu, Z.Q., Z.J. Xia, A.M. Wu, Y.H. Yang and Q. Zheng et al., 1999. The mechanism for controlling cotton wilt (Verticillium dahliae) by endophytic bacteria. Jiangsu J. Agric. Sci., 15: 211-215.

Gilligan, 1983. Modeling of soilborne pathogens. Ann. Rev. Phytopathol., 21: 45-64.

DOI: 10.1146/annurev.py.21.090183.000401

Gopalakrishnana, S., P. Humayuna, V. Srinivas, V. Rajendran and K.B. Bhiminenia et al., 2012. Plant growth-promoting traits of Streptomyces with biocontrol potential isolated from herbal vermicompost. Biocontrol Sci. Technol., 22: 1199-1210. DOI: 10.1080/09583157.2012.719151

Hamilton, C.E., T.E. Dowling and S.H. Faeth, 2010. Hybridization in endophyte symbionts alters host response to moisture and nutrient treatments. Microb. Ecol., 59: 768-775.

DOI: $10.1007 / \mathrm{s} 00248-009-9606-9$

Hatwalene, 1993. Effect of bioloigical nitrogen fixers and VAM on the yield and dry matter production of sorghum SPH (468). Ph.D. Thesis, India.

He, R., G. Wang, X. Liu, C. Zhang and C. Lin, 2009. Antagonistic bioactivity of an endophytic bacterium isolated from Epimedium brevicornu Maxim. Afr. J. Biotechnol., 8: 191-195.

Hipol, R.M., 2012. Molecular identification and phylogenetic affinity of two growth promoting fungal endophytes of sweet potato (Ipomea batatas (L.) Lam.) from Baguio City, Philippines. eJ Bio., 8: 57-61.

Holland, M.A., 1997. Occam's razor applied to hormonology: Are cytokinins produced by plants? Plant Physiol., 115: 865-868. PMID: 12223849

Hung, P.Q. and K. Annapurna, 2004. Isolation and characterization of endophytic bacteria in soybean (Glycine sp.). Omonrice, 12: 92-101.

Jackson, M.L., 1973. Soil chemical analysis. Prentice Hall of India Pvt. Ltd, New Delhi, pp: 111-203. 
Khan, A.L., M. Hamayun, S.M. Kang, Y.H. Kim and H.Y. Jung et al., 2012. Endophytic fungal association via gibberellins and indole acetic acid can improve plant growth under abiotic stress: An example of Paecilomyces formosus LHL10. BMC Microbiol., 12: 1-14. DOI: 10.1186/1471-2180-12-3

Khan, A.L., M. Hamayun, Y.H. Kim, S.M. Kang and I.J. Lee, 2013. Ameliorative symbiosis of endophyte (Penicillium funiculosum LHL06) under salt stress elevated plant growth of Glycine $\max$ L. Plant Physiol. Biochem., 49: 852-862. DOI:10.1016/j.plaphy.2011.03.005

Khan, Z. and S.L. Doty, 2009. Characterization of bacterial endophytes of sweet potato plants. Plant Soil, 322: 197-207.

DOI: $10.1007 / \mathrm{s} 11104-009-9908-1$

Logeshwaran, P., M. Thangaraju and K. Rajasundari 2009. Hydroxamate siderophores of endophytic bacteria Gluconacetobacter diazotrophicus isolated from sugarcane roots. Austral. J. Basic Appl. Sci., 3: 3564-3567.

Lorck, H., 2006. Production of hydrocyanic acid by bacteria. Plant Physiol., 1:142-146. DOI: 10.1111/j.1399-3054.1948.tb07118.x

Meenakshi, B.C., 2008. Performance of methylotrophs in soybean (Glycine $\max$ (L.) Merrill) under field conditions. Msc Thesis, Department of Agricultural Microbiology, Dharwad University of Agricultural Sciences, Dharwad, India.

Melnick, R.L., N.K. Zidack, B.A. Bailey, S.N. Maximova and M. Guiltinan et al., 2008. Bacterial endophytes: Bacillus spp. from annual crops as potential biological control agents of black pod rot of cacao. Biol. Control., 46: 46-56. DOI: 10.1016/j.biocontrol.2008.01.022

Mendes, R., A.A. Pizzirani-Kleiner, W.L. Araujo and J.M. Raaijmakers, 2007. Diversity of cultivated endophytic bacteria from sugarcane: Genetic and biochemical characterization of Burkholderia cepacia complex isolates. Appl. Environ. Microbiol., 73: 7259-7267. DOI: 10.1128/AEM.01222-07

Mondal, K.K., R.P. Singh and 1.P. Verma, 1999. Beneficial effects of indigenous cotton rhizobacteria on seed germinability, growth promotion and suppression of bacterial blight disease. Indian Phytopathol., 52: 228-235.

Mucciarelli, M., S. Scannerini, M. Cinzia, M. Bertea and M. Maffei, 2002. An ascomycetous endophyte isolated from Mentha piperita L.: Biological features and molecular studies. Mycologia, 94: 28-390. DOI: $10.2307 / 3761843$

Namrata, K., P. Namrata, K., P.W. Basarkar, H.B. Babalad and M.N. Sreenivasa, 2012. Yield, yield attributes and economics of soybean as influenced by homa organic farming practices. Karnataka J. Agric. Sci., 25: 270-272.
Neilands, J.B., 1981. Iron absorption and transport in microorganisms. Annu. Rev. Nutr., 1: 27-46. DOI: 10.1146/annurev.nu.01.070181.000331

Pawar, R.S., V.M. Wagh, D.B. Panaskar, V.A. Adaskar and P.R. Pawar, 2011. A Case study of soybean crop production, installed capacity and utilized capacity of oil plants in Nanded district, Maharashtra, India. Adv. Applied Sci. Res., 2: 342-350.

Prieto, P., E. Schilirò, M.M. Maldonado-González, R. Valderrama and J.B. Barroso-Albarracín et al., 2011. Root hairs play a key role in the endophytic colonization of olive roots by Pseudomonas spp. with biocontrol activity. Microb. Ecol., 62: 435-445. DOI: $10.1007 / \mathrm{s} 00248-011-9827-6$

Rajendran, L., D. Saravanakumar, T. Raguchander and R. Samiyappan, 2006. Endophytic bacterial induction of defence enzymes against bacterial blight of cotton. Phytopathol. Mediterr., 45: 203-214.

Redman, R.S., Y.O. Kim, C.D.J.A. Woodward, C. Greer and L. Espino et al., 2011. Increased fitness of rice plants to abiotic stress via habitat adapted symbiosis: A strategy for mitigating impacts of climate change. PLoS One, 6: e14823.

DOI: 10.1371/journal.pone.0014823

Rodriguez, R.J., J.F. White Jr., A.E. Arnold and R.S. Redman, 2009. Fungal endophytes: Diversity and functional roles. New Phytologist, 182: 314-330. DOI: $10.1111 /$ j.1469-8137.2009.02773.x

Ryan, R.P., K. Germaine, A. Franks, D.J. Ryan and D.N. Dowling, 2008. Bacterial endophytes: Recent developments and applications. FEMS Microbiol. Lett., 278: 1-9.

DOI: 10.1111/j.1574-6968.2007.00918.x 1-9

Samuel, S. and S.M. Muthukkaruppan, 2011. Characterization of plant growth promoting rhizobacteria and fungi associated with rice, mangrove and effluent contaminated soil. Curr. Bot., 2: $22-25$.

Shirling, E.B. and D. Gottlieb, 1966. Methods for characterization of Streptomyces species. Int. J. Syst. Bacteriol., 16: 313-340.

DOI: $10.1099 / 00207713-16-3-313$

Stein, T., 2005. Bacillus subtilis antibiotics: structures, syntheses and specific functions. Mol. Microbiol., 56: 845-857. DOI: $10.1111 / \mathrm{j} .1365-2958.2005 .04587 . x$

Strobel, G. and B. Daisy, 2003. Bioprospecting for microbial endophytes and their natural products. Microbiol. Mol. Biol. Rev., 67: 491-502. DOI: 10.1128/MMBR.67.4.491-502.2003

Strzelczyk, E. and A. Pokojska-Burdziej, 1984. Production of auxins and gibberellin-like substances by mycorrhizal fungi, bacteria and actinomycetes isolated from soil and the mycorrhizosphere of pine (Pinus silvestris L.). Plant Soil, 81: 185-194. DOI: $10.1007 / \mathrm{BF} 02197150$ 
Sudisha, J., S.R. Niranjana, S. Umesha, H.S. Prakash and H.S. Shetty, 2006. Transmission of seed-borne infection of muskmelon by Didymella bryoniae and effect of seed treatments on disease incidence and fruit yield. Bio. Control, 37: 196-205.

DOI: 10.1016/j.biocontrol.2005.11.018

Thimmaiah, S.R., 2004. Standard Methods of Biochemical Analysis. 1st Edn., Kalyani Publishers, pp: 545.

Tien, T.H., M.H. Gaskins and D.H. Hubbel, 1979. Plant growth substances produced by azospirillum brasilense and their effect on the growth of pearl millet (Pennisetum americanum L.). Appl. Environ. Microbiol., 37: 1016-1024.

Totawar, M.V., 2001. Comparative antagonistic studies of Trichoderma spp. and some mutantagainst Rhizoctonia bataticola. MSc Thesis, Department of Plant Pathology, India.

Waller, F., B. Achatz, H. Baltruschat, J. Fodor and K. Becker et al., 2005.The endophytic fungus Piriformis indica reprograms barley to salt stress tolerance, disease resistance and higher yield. PNAS, 102: 13386-13391. DOI: $10.1073 /$ pnas.0504423102

Wang, Y., Q.G. Zeng, Z.B. Zhang, R.M. Yan and D. Zhu, 2010. Antagonistic bioactivity of an endophytic bacterium H-6. Afr. J. Biotechnol., 9: 6140-6145.

Wei, G., J.W. Kloepper and S. Tuzun, 1996. Induced systemic resistance to cucumber diseases and increased plant growth by plant growth-promoting rhizobacteria under field conditions. Phytopathology, 86: 221-224.

Wijesundera, R.L.C., A.S. Amarasekera and D.N.D. Yapa, 1995. Production of a siderophore by the fungus Fusarium oxysporum. J. Natn. Sci. Foundation Sri Lanka, 23: 97-100.

DOI: $10.4038 /$ jnsfsr.v23i3.5846
Wilson, D. 1995. Endophyte: The evolution of a term and clarification of its use and definition. Oikos, 73: 274-276. DOI: 10.2307/3545919

Yan, Z., M.S. Reddy, C.M. Ryu, J.A. McInroy and M. Wilson et al., 2002. Induced systemic protection against tomato late blight elicited by plant growth-promoting rhizobacteria. Phytopathology, 92: 1329-1333.

DOI: 10.1094/PHYTO.2002.92.12.1329

Yuan, W.M. and D.L. Crawford, 1995. Characterization of streptomyces lydicus WYEC108 as a potential biocontrol agent against fungal root and seed rots. Appl. Environ. Microbiol., 61: 3119-3128.

Zehnder, G.W., J.F. Murphy, E.J. Sikora and J.W. Kloepper, 2001. Application of rhizobacteria for induced resistance. Eur. J. Plant Pathol., 107: 39-50. DOI: 10.1023/A:1008732400383

Zinniel, D.K., N.B. Lambrecht, Z.F. Harris, D. Kuczmarski and P. Higley et al., 2002. Isolation and characterization of endophytic colonizing bacteria from agronomic crops and prairie plants. Appl. Environ. Microbiol., 68: 2198-2208.

DOI: 10.1128/AEM.68.5.2198-2208.2002

Zivkovic, V., Z. Stojanovic, Z. Ivanovic, V. Gavrilovic and T. Popovic et al., 2010. Screening of antagonistic activity of microorganisms against colletotrichum acutatum and Colletotrichum gloeosporioides. Arch. Biol. Sci., 62: 611-623. DOI: 10.2298/ABS1003611 